\title{
Toxic Heavy Metals in Sediments of Mahul Creek near Mumbai, India
}

\author{
Pravin U. Singare ${ }^{1, *}$, M. V. A. Ansari ${ }^{1}$, N. N. Dixit $^{2}$ \\ ${ }^{1}$ Department of Chemistry, Bhavan's College, Munshi Nagar, Andheri (West), \\ Mumbai - 400058, India \\ ${ }^{2}$ Department of Chemistry, Maharashtra College, Jahangir Boman Behram Marg, Nagpada, \\ Mumbai - 400008, India \\ *E-mail address: pravinsingare@gmail.com
}

\begin{abstract}
The present study was performed for the period of one year from January 2013 to December 2013 in order to understand the level of toxic heavy metals in the sediments of Mahul Creek near Mumbai. The annual average concentration of heavy metals like $\mathrm{Cr}, \mathrm{Zn}, \mathrm{Cu}, \mathrm{Ni}, \mathrm{Pb}, \mathrm{Cd}, \mathrm{As}$ and $\mathrm{Hg}$ was found to be $277.5,121.7,100.3,63.8,21.5,14.6,10.4$ and 4.9 ppm respectively. It is feared that this heavy metals accumulated in the creek sediments may enter the water thereby creating threat to the biological life of an aquatic ecosystem. The results of present study indicates that the existing situation if mishandled can cause irreparable ecological harm in the long term well masked by short term economic prosperity due to extensive industrial growth.
\end{abstract}

Keywords: industrial effluents; heavy metals; toxic metals; creek sediments; Mahul Creek; Mumbai

\section{INTRODUCTION}

During the past few decades Indian industries have registered a quantum jump, which has contributed to high economic growth but simultaneously it has also given rise to severe environmental pollution [1-16]. Consequently, the water quality is seriously affected which is far lower in comparison to the international standards. Waste water from manufacturing or chemical processing industries contributes to water pollution. Industrial waste water usually contains specific and readily identifiable chemical compounds. It is found that one-third of the total water pollution comes in the form of effluent discharge, solid wastes and other hazardous wastes. Out of this a large portion can be traced to the processing of industrial chemicals and to the food products industry. The pollution impacts on marine communities $[17,18]$ can be traced directly to the industrialized centres, which release an array of chemical contaminants to effluent systems. According to one estimate it was reported that Mumbai city of India itself discharges around 2200 MLD of waste to the coastal waters [19]. Among the different pollutants entering the water bodies, heavy metals are of great concern.

These toxic heavy metals entering the aquatic ecosystem may lead to geoaccumulation, bioaccumulation and biomagnifications; further they may also enter the food chain [20-26]. Food chain contamination by heavy metals has become a burning issue in recent years because of their potential accumulation in bio-systems through contaminated water and sediments. In hydrosphere, concentrations of toxic metal are typically orders of magnitude 
greater in the sediments as compared to those in overlying waters [27-37]. The capacity of sediments to accumulate most of these heavy metals make them useful and sensitive indicators for monitoring changes in the aquatic environment. Therefore for better understanding of heavy metal sources, their accumulation in the aquatic sediments seem to be particularly important issues of present day research on risk assessments [27-37].

The present day by day increasing pollution level along most of the creeks and rivers in Mumbai have prompted us to conduct the systematic study of pollution along the Mahul creek of Mumbai which receives heavy pollution load from the surrounding refineries, agrochemical and other industries and also domestic effluent from the surrounding slum areas.

\section{EXPERIMENTAL}

\section{1. Study Area}

Mahul Creek $\left(19^{\circ} 01^{\prime} \mathrm{N} \& 72^{\circ} 53^{\prime} \mathrm{E}\right)$ lying on the east coast of Mumbai along the Arabian sea, is situated in Chembur suburban the north eastern corner of Mumbai about 15 $\mathrm{km}$ from Victoria Terminus (presently known as Chhatrapati Shivaji Terminus). The temperature of the area ranges between $13{ }^{\circ} \mathrm{C}$ to $39{ }^{\circ} \mathrm{C}$. The south west monsoon (June to mid-October) brings rain to the area which is recorded maximum $747 \mathrm{~mm}$ during July. The climate is humid and relative humidity ranges between 29 to $96 \%$ [38].

\section{2. Sediment Sampling}

The study on pollution status along the Mahul Creek of Mumbai was performed for the period of one year from January 2013 to December 2013. The grab sediment samples were collected every month along different locations of the creek. The sampling was done by hand-pushing plastic core tubes with an intention to avoid metallic contamination. Samples so collected were kept in polythene bags which were free from heavy metals and organic contaminants. The samples were well covered while transporting from field to the laboratory to avoid contamination from the environment.

The samples thus collected were mixed to give gross sample. The gross samples were air dried, ground using agate mortar and sieved with a $0.5 \mathrm{~mm}$ mesh size sieve to uniform particle size. The thoroughly mixed sediment samples were packed in polythene bags and kept in a dry place until analysis. Such samples were drawn and analysed monthly for their toxic heavy metal content, so as to get the seasonal variation in pollution level along the Mahul Creek.

\section{3. Sample Preparation}

For analysis of heavy metal content in sediment samples, well mixed sample weighing $2 \mathrm{~g}$ was digested with $8 \mathrm{~mL}$ of aqua regia on a sand bath for $2 \mathrm{~h}$. After evaporation to near dryness, the sample was dissolved in $2 \%$ nitric acid, filtered through Whatman's No. 1 filter paper and then diluted with deionized water to give final volumes depending on the suspected level of the metals [39].

\section{3. Analysis of Heavy Metals}

The sediment samples collected were analyzed for the heavy metal content. The analysis for the majority of the trace metals like lead $(\mathrm{Pb})$, copper $(\mathrm{Cu})$, zinc $(\mathrm{Zn})$, nickel $(\mathrm{Ni})$, cadmium $(C d)$ and chromium $(C r)$ in sediment samples was done by Flame Atomic 
Absorption spectrophotometer $(A A S)$ technique, while analysis of mercury $(H g)$ and Arsenic $(A s)$ was performed by cold-vapour and by hydride generation techniques coupled with an atomic fluorescence detector [40].

\section{RESULTS AND DISCUSSION}

Although there is no clear definition of what a heavy metal is, density is in most cases taken to be the defining factor. Heavy metals are thus generally defined as those having a specific density of more than $5 \mathrm{~g} / \mathrm{cm}^{3}$. Heavy metals are among the most common environmental pollutants, and their occurrence in waters and biota indicate the presence of natural or anthropogenic sources. Although adverse health effects of heavy metals have been known for a long time, discharge of heavy metals continues and is even increasing in some areas, in particular in less developed countries. The main threats to human health from heavy metals are associated with exposure to lead, cadmium, mercury and arsenic (arsenic is a metalloid, but is usually classified as a heavy metal). Their accumulation and distribution in soil, sediments and aquatic environment are increasing at an alarming rate thereby affecting marine life [41-43]. The experimental data on concentration ( $\mathrm{ppm}$ ) of toxic heavy metals like $\mathrm{Cr}, \mathrm{Pb}, \mathrm{Cu}, \mathrm{Ni}, \mathrm{Zn}, \mathrm{Cd}, \mathrm{As}$ and $\mathrm{Hg}$ in the sediment samples collected along the Mahul Creek of Mumbai is presented in Table 1. The annual average concentration of these metals is graphically represented in Figure 1.

From the results of our study, it was observed that the concentration of $\mathrm{Pb}$ in the creek sediment was found to vary in the range of 10-40 ppm with an annual average concentration of $21.5 \mathrm{ppm}$. It is feared that the $P b$ which is accumulated in the sediments might enter the creek water thereby increasing its concentration in aquatic environment. Such high concentration of $\mathrm{Pb}$ might create adverse metabolic effects and might also affects hematopoietic, vascular, nervous, renal, and reproductive systems [44-49].

Table 1. Heavy metals in the sediments of Mahul Creek near Mumbai.

\begin{tabular}{|c|c|c|c|c|c|c|c|c|c|c|c|c|}
\hline $\begin{array}{c}\begin{array}{c}\text { Sampling } \\
\text { Months/Year }\end{array} \\
\\
\begin{array}{c}\text { Heavy } \\
\text { Metals } \\
(p p m)\end{array}\end{array}$ & 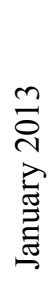 & 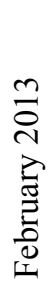 & 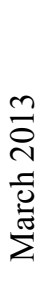 & 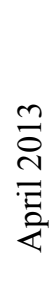 & 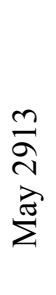 & $\begin{array}{l}\stackrel{m}{ٍ} \\
\text { I } \\
\stackrel{\Xi}{\Xi}\end{array}$ & 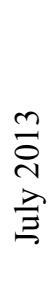 & 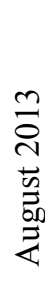 & 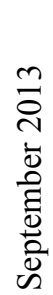 & 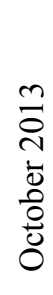 & 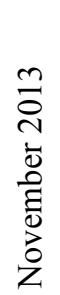 & 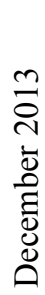 \\
\hline$P b$ & $\stackrel{8}{\circ}$ & $\begin{array}{l}8 \\
\ddot{n}\end{array}$ & $\begin{array}{l}8 \\
\dot{I}\end{array}$ & $\begin{array}{l}8 \\
\text { ते }\end{array}$ & \&. & $\begin{array}{l}8 \\
\stackrel{\sim}{\circ}\end{array}$ & 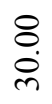 & $\begin{array}{l}8 \\
\infty \\
\stackrel{\sim}{\sim}\end{array}$ & $\begin{array}{l}8 \\
\stackrel{+}{0}\end{array}$ & $\begin{array}{l}8 \\
\dot{+}\end{array}$ & $\stackrel{8}{\circ}$ & $\begin{array}{l}8 \\
\stackrel{\sim}{\circ}\end{array}$ \\
\hline$C u$ & $\begin{array}{l}8 \\
\dot{8}\end{array}$ & $\begin{array}{l}8 \\
\stackrel{0}{1}\end{array}$ & $\begin{array}{l}8 \\
\dot{a} \\
\stackrel{n}{n}\end{array}$ & $\begin{array}{l}8 \\
\stackrel{8}{0} \\
\stackrel{0}{\simeq}\end{array}$ & \begin{tabular}{l}
8 \\
$\stackrel{0}{0}$ \\
\multirow{2}{*}{}
\end{tabular} & $\begin{array}{l}8 \\
\stackrel{8}{0}\end{array}$ & $\begin{array}{l}\stackrel{8}{\circ} \\
\stackrel{\Xi}{=}\end{array}$ & $\begin{array}{l}8 \\
8 \\
8\end{array}$ & $\begin{array}{l}8 \\
\dot{\infty}\end{array}$ & $\begin{array}{l}8 \\
\infty \\
\infty\end{array}$ & $\begin{array}{l}8 \\
\dot{8} \\
\stackrel{0}{0}\end{array}$ & $\underset{\infty}{8}$ \\
\hline
\end{tabular}




\begin{tabular}{|c|c|c|c|c|c|c|c|c|c|c|c|c|}
\hline$Z n$ & 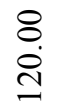 & $\begin{array}{l}8 \\
\stackrel{n}{n} \\
\text { n }\end{array}$ & $\begin{array}{l}8 \\
\stackrel{0}{\circ} \\
\stackrel{n}{n}\end{array}$ & $\begin{array}{l}8 \\
\text { ల్ }\end{array}$ & $\begin{array}{l}8 \\
: \\
\stackrel{0}{0}\end{array}$ & $\begin{array}{l}8 \\
\stackrel{8}{\circ}\end{array}$ & $\begin{array}{l}8 \\
\stackrel{0}{0} \\
\end{array}$ & $\begin{array}{l}8 \\
\stackrel{0}{0} \\
\end{array}$ & $\begin{array}{l}8 \\
\stackrel{0}{0} \\
=\end{array}$ & $\begin{array}{l}\stackrel{8}{0} \\
\stackrel{8}{0}\end{array}$ & 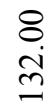 & $\begin{array}{l}8 \\
\stackrel{\infty}{0}\end{array}$ \\
\hline$N i$ & $\begin{array}{l}8 \\
8 \\
8\end{array}$ & $\begin{array}{l}8 \\
\dot{a} \\
\text { a }\end{array}$ & $\stackrel{8}{8}$ & $\begin{array}{l}8 \\
8\end{array}$ & $\begin{array}{l}8 \\
:\end{array}$ & ¿ & $\begin{array}{l}8 \\
\text { in }\end{array}$ & $\begin{array}{l}8 \\
\dot{\infty}\end{array}$ & $\begin{array}{l}8 \\
\dot{q}\end{array}$ & $\begin{array}{l}8 \\
8\end{array}$ & : & $\begin{array}{l}8 \\
\text { \& }\end{array}$ \\
\hline$C d$ & $\underset{i}{8}$ & $\stackrel{8}{\circ}$ & $\stackrel{8}{\circ}$ & $\begin{array}{l}8 \\
\stackrel{\text { }}{0}\end{array}$ & $\stackrel{8}{\rightarrow}$ & $\stackrel{8}{\stackrel{8}{I}}$ & $\begin{array}{l}\stackrel{8}{0} \\
\stackrel{+}{0}\end{array}$ & $\begin{array}{l}8 \\
\text { i }\end{array}$ & $\begin{array}{l}8 \\
\stackrel{+}{~}\end{array}$ & $\begin{array}{l}\stackrel{8}{\infty} \\
\infty\end{array}$ & $\begin{array}{l}8 \\
\stackrel{\sim}{1}\end{array}$ & $\stackrel{8}{\circ}$ \\
\hline$H g$ & $\underset{\sim}{\stackrel{8}{0}}$ & $\stackrel{8}{\circ}$ & $\stackrel{8}{8}$ & $\underset{i}{\stackrel{8}{i}}$ & $\stackrel{8}{8}$ & $\underset{\mathrm{i}}{\stackrel{8}{ }}$ & $\underset{i}{\stackrel{8}{ }}$ & $\underset{\infty}{\stackrel{\infty}{\infty}}$ & $\stackrel{8}{\circ}$ & $\underset{\mathrm{i}}{\stackrel{8}{ }}$ & $\stackrel{8}{\stackrel{\circ}{-}}$ & $\underset{+}{\stackrel{+}{\circ}}$ \\
\hline As & $\underset{\infty}{\stackrel{\infty}{0}}$ & $\underset{+}{\stackrel{8}{\circ}}$ & $\underset{i}{\stackrel{8}{0}}$ & $\stackrel{8}{\circ}$ & $\underset{\infty}{\stackrel{\infty}{\infty}}$ & $\begin{array}{l}8 \\
\stackrel{2}{-}\end{array}$ & $\begin{array}{l}8 \\
\text { in }\end{array}$ & $\begin{array}{l}\stackrel{8}{0} \\
\text { ते }\end{array}$ & $\begin{array}{l}8 \\
\stackrel{i}{1}\end{array}$ & $\stackrel{8}{\circ}$ & $\stackrel{8}{\circ}$ & $\underset{\infty}{\stackrel{\infty}{0}}$ \\
\hline $\mathrm{Cr}$ & $\begin{array}{l}8 \\
\dot{8} \\
\stackrel{8}{0}\end{array}$ & $\begin{array}{l}8 \\
\dot{0} \\
\infty \\
\infty\end{array}$ & $\begin{array}{l}8 \\
\text { ¿ } \\
\text { ஸे }\end{array}$ & $\underset{m}{\stackrel{8}{8}}$ & $\begin{array}{l}8 \\
\stackrel{8}{0} \\
\stackrel{0}{0}\end{array}$ & $\begin{array}{l}8 \\
\dot{0} \\
\dot{8}\end{array}$ & $\begin{array}{l}8 \\
\stackrel{0}{0} \\
\stackrel{1}{2}\end{array}$ & $\begin{array}{l}8 \\
\dot{\infty} \\
\infty\end{array}$ & $\begin{array}{l}8 \\
\stackrel{8}{0} \\
\stackrel{ }{0}\end{array}$ & $\begin{array}{l}8 \\
\dot{0} \\
\stackrel{2}{1}\end{array}$ & $\begin{array}{l}8 \\
\dot{+} \\
\text { mे }\end{array}$ & $\begin{array}{l}8 \\
\dot{8} \\
\text { के }\end{array}$ \\
\hline
\end{tabular}

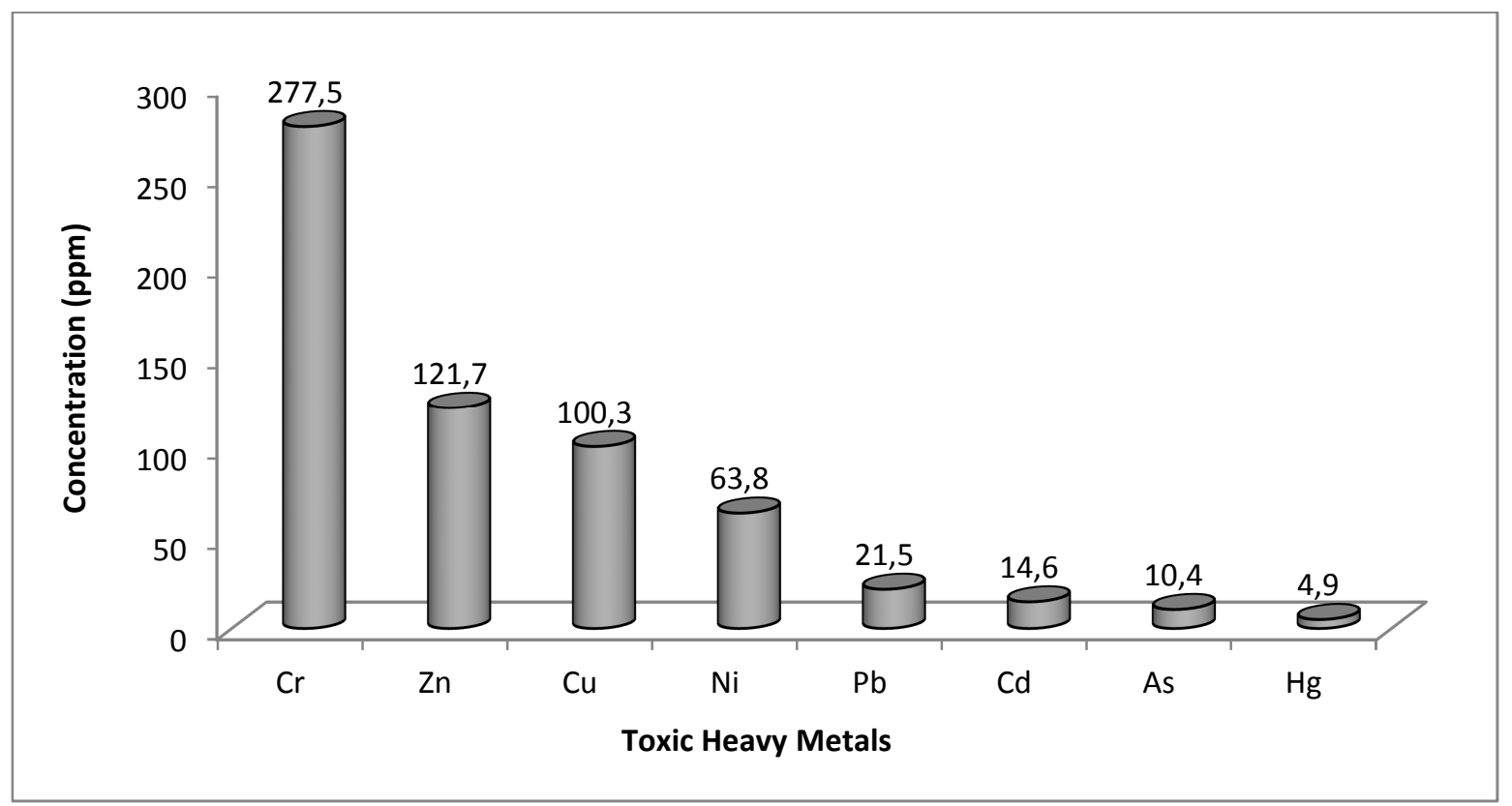

Figure 1. Annual average concentrations of Heavy metals in the sediments of Mahul Creek.

The results also indicates that the $C u$ concentration in the sediment samples was found to be minimum of $60 \mathrm{ppm}$ in the month of August and maximum of $135 \mathrm{ppm}$ in the month of March. The annual average concentration of $C u$ was found to be $100.3 \mathrm{ppm}$. $C u$ is highly toxic to most fishes, invertebrates and aquatic plants than any other heavy metal except 
mercury. It reduces growth and rate of reproduction in plants and animals. The chronic level of $C u$ is $0.02-0.2 \mathrm{ppm}$ [50]. It was reported that the aquatic plants absorb three times more $C u$ than plants on dry lands [51]. Excessive $C u$ content can cause damage to roots, by attacking the cell membrane and destroying the normal membrane structure, inhibited root growth and formation of numerous short, brownish secondary roots [50]. Copper is highly toxic in aquatic environments and has effects in fish, invertebrates, and amphibians, with all three groups equally sensitive to chronic toxicity $[52,53]$. Copper will bio concentrate in many different organs in fish and molluscs. Copper also causes reduced sperm and egg production in many species of fish, such as fathead minnows, as well as early hatching of eggs, smaller fry (newly hatched fish) and increased incidence of abnormalities and reduced survival in the fry [54]. The concentration of $Z n$ in the creek sediments was found to vary in the range of 80$163 \mathrm{ppm}$ with an annual average concentration of $121.7 \mathrm{ppm}$. Nickel $(\mathrm{Ni})$ and nickel compounds have many industrial and commercial uses, and the progress of industrialization has resulted in increased emission of pollutants into ecosystems. In the present study it was observed that the concentration of $\mathrm{Ni}$ in the sediment samples was found to be minimum of $30 \mathrm{ppm}$ in the month of June and $95 \mathrm{ppm}$ in the month of February, having annual average concentration of $63.8 \mathrm{ppm}$. Although $\mathrm{Ni}$ is omnipresent and is vital for the function of many organisms, concentrations in some areas from both anthropogenic release and naturally varying levels may be toxic to living organisms $[55,56]$.

Nickel compounds have been well established as carcinogenic in many animal species and by many modes of human exposure but their underlying mechanisms are still not fully understood [57]. $C d$ is typically a metal of the $20^{\text {th }}$ century, and is mainly used in rechargeable batteries and for the production of special alloys. It was the outbreak of the ItaiItai bone disease in Japan in the 1960s that really drew the attention of the public and regulatory bodies to this heavy metal that had been discharged in the environment at an uncontrolled rate for more than one century. From the results of our study, it was observed that the $C d$ concentration in the creek sediments was found to vary in the range of 5 to 22 $\mathrm{ppm}$ with an annual average concentration of $14.6 \mathrm{ppm}$. $C d$ dispersed in the environment can persist in soils and sediments for decades. When taken up by plants, $C d$ concentrates along the food chain and ultimately accumulates in the body of people eating contaminated foods. By far, the most salient toxicological property of $C d$ is its exceptionally long half-life in the human body. Once absorbed, $C d$ irreversibly accumulates in the human body, in particularly in kidneys, the bone, the respiratory tract and other vital organs such the lungs or the liver [58]. In addition to its extraordinary cumulative properties, $C d$ is also a highly toxic metal that can disrupt a number of biological systems, usually at doses that are much lower than most toxic metals [59-61]. $\mathrm{Hg}$ poisoning has become a problem of current interest as a result of environmental pollution on a global scale. High concentration of mercury, which could pose an ecological hazard, leading to contamination of plants, aquatic resources and bioaccumulation in the food chain [62].

The results of present investigation indicates that the concentration of $\mathrm{Hg}$ in the sediments was in the range of 1 to 9 ppm having the annual average concentration of 4.9 ppm. Recently, the anthropogenic activities such as treatment of agricultural land with arsenical pesticides, treating of wood using chromated copper arsenate, burning of coal in thermal plants power stations and the operations of gold-mining have increased the environmental pervasiveness of $A s$ and its rate of discharge into freshwater habitat [63]. As can also interfere with the fish immune system by suppressing antibody production [64] as well as by lowering macrophage activity and maturation [65]. From the results of our study it was observed that the As concentration in the creek sediments was lowest of $2 \mathrm{ppm}$ in the month of March and highest of $20 \mathrm{ppm}$ in the month of August and September with an annual average concentration of $10.4 \mathrm{ppm}$. $\mathrm{Cr}$ is one of the most common skin sensitizers and often 
causes skin sensitizing effect in the general public. A possible source of chromium exposure is waste dumps for chromate-producing plants causing local air or water pollution. Penetration of the skin will cause painless erosive ulceration ("chrome holes") with delayed healing. These commonly occur on the fingers, knuckles, and forearms. The characteristic chrome sore begins as a papule, forming an ulcer with raised hard edges. Besides the lungs and intestinal tract, the liver and kidney are often target organs for chromate toxicity [66-72]. The results obtained in our study indicate that the concentration of $\mathrm{Cr}$ in the sediment samples was in the range of 100-380 ppm with an average concentration of $277.5 \mathrm{ppm}$.

\section{CONCLUSIONS}

The ecological and human health safety due to discharge of heavily polluted industrial effluents are undoubtedly under threat. The present experimental data on environmental risk assessment studies due to agrochemical and pesticides manufacturing industries may be regarded as an aid towards a better understanding of the problem arising due to such industries. There is a need to convey the message that prevention of adverse health effects and promotion of health are profitable investments for employers and employees as a support to a sustainable development of economics. From the results of the present investigation it seems that the time has come to move towards ecosystem specific discharge standards to maintain the health and productivity of natural resources on which the majority of Indians are dependent. These are possible by proper treatment of effluent water and enforcement of pollution control by the regulatory authority on the indiscriminate discharge of industrial wastewater into water bodies should be carried out. Educating the urban as well as the rural mass is another major step to put a check on such industrial pollution. Masses should be made aware of the drastic consequences of such industrial pollution on their lives, both directly and indirectly. The existing situation if mishandled can cause irreparable ecological harm in the long term well masked by short term economic prosperity due to extensive industrial growth.

\section{References}

1. P.U. Singare, R.S. Lokhande, A.G. Jagtap, International Journal of Global Environmental Issues, 11(1), 28-36 (2011).

2. P.U. Singare, R.S. Lokhande, A.G. Jagtap, Interdisciplinary Environmental Review, 11(4), 263-273 (2010).

3. R.S. Lokhande, P.U. Singare, D.S. Pimple, World Environment, 1(1), 6-13 (2011).

4. R.S. Lokhande, P.U. Singare, D.S. Pimple, Resources and Environment, 1(1):13-19(2011)

5. R.S. Lokhande, P.U. Singare, D.S. Pimple, International Journal of Ecosystem, 1(1), 1-9 (2011).

6. S.K. Sasamal, K.H. Rao, U.M. Suryavansi, International J. Remote Sensing, 28(19), 43914395 (2007).

7. A. Nagaraju, S. Suresh, K. Killham, K. Hudson-Edward, Turkish J. Eng. Env. Sci., 30(4), 203-219 (2006).

8. T. Rajaram, A. Das, Futures, 40, 56 (2008). 
9. M.D. Zingade, M.M. Sabnis, A.V. Mandalia, B.N. Desai, Mahasagar Bull. Natn. Inst. Occeonagr., 13, 99 (1980).

10. P.U. Singare, S.S. Dhabarde, International Letters of Chemistry, Physics and Astronomy, 3 (2014) 56-63.

11. P.U. Singare, S.S. Dhabarde, International Letters of Chemistry, Physics and Astronomy, 3 (2014) 48-55.

12. P.U. Singare, S.S. Dhabarde, International Letters of Chemistry, Physics and Astronomy, 3 (2014) 40-47.

13. P.U. Singare, S.S. Dhabarde, International Letters of Chemistry, Physics and Astronomy, 3 (2014) 32-39.

14. P.U. Singare, S.S. Dhabarde, International Letters of Chemistry, Physics and Astronomy, 3 (2014) 8-15.

15. P.U. Singare, S.S. Dhabarde, International Letters of Chemistry, Physics and Astronomy, 3 (2014) 16-23.

16. P.U. Singare, S.S. Dhabarde, International Letters of Chemistry, Physics and Astronomy, 3 (2014) 24-31.

17. A. Aghor, 'Chemicals make Thane creek the worst polluted water body'. Daily $D N A$. August 14, 2007. Mumbai, India. Obtained through the Internet:

http://www.dnaindia.com/mumbai/report_chemicals-make-thane-creek-the-worstpolluted-waterbody_1115439 [accessed 01/03/2010].

18. D. Patil, 'A lot's fishy about our creek and lake fish'._Daily Times of India. March 22, 2009. Mumbai, India. Obtained through the Internet:

http://timesofindia.indiatimes.com/city/thane/A-lots-fishy-about-our-creek-and-lakefish/articleshow/4298566.cms [accessed 01/03/2010].

19. M.D. Zingde, K. Govindan, Health status of coastal waters of Mumbai and regions around. In: Environmental Problems of Coastal Areas in India (ed. V.K. Sharma), Bookwell Publishers., New Delhi, pp. 119-132 (2001).

20. P.U. Singare, M.S. Talpade, D.V. Dagli, V.G. Bhawe, International Letters of Chemistry, Physics and Astronomy 8(2) (2013) 105-112.

21. P.U. Singare, M.S. Talpade, Interdisciplinary Environmental Review 14(1), 59-68 (2013)

22. M.C. Kennicutt, T.L. Wade, B.J. Presley, A.G. Requejo, J.M. Brooks, G.J. Denoux, Environ. Sci. Technol., 28, 1 (1993).

23. W.J. Adams, R.A. Kimerle, J.W. Barnett Jr., Environ. Sci. Technol., 26, 1864 (1992).

24. R. K. Sharma, M. Agrawal, F.M. Marshall, 'Effects of waste water irrigation on heavy metal accumulation in soil and plants', Paper presented at a National Seminar, Bangalore University, Bangalore, Abst. no. 7, pp. 8 (2004).

25. D.P. Weston, K.A. Maraya, Environ. Toxicol. Chem., 21, 962 (2002).

26. A. Kumar, Pol. Arch. Hydrobiol., 18, 469 (1996).

27. S. K. Jha, S. B. Chavan, G. G. Pandit, B. S. Negi, S. Sadasivan, Environmental Monitoring and Assessment, 76, 249 (2002). 
28. S.K. Sahu, P.Y. Ajmal, G.G. Pandit, V.D. Puranik, Journal of hazardous materials, 164, 1573 (2009).

29. W. Maher, G.E. Batley, I. Lawrence, Freshw Biol., 41, 361 (1999).

30. S. Sanjgiri, A. Mesquita, T.W. Kureshi, Mar. Pollut. Bull., 19, 339 (1988).

31. B.G. Lee, S.B. Griscom, J.S. Lee, H.J. Choi, C.H. Koh, S.N. Luoma, N.S. Fisher, Science 287, 282 (2000).

32. S.K. Jha, T.M. Krishnamoorthy, G.G. Pandit, K.S.V. Nambi, Science of the total Environment, 236, 91 (1999).

33. P. U. Singare, R.M. Mishra, M.P. Trivedi, Advances in Analytical Chemistry, 2(3), 14-24 (2012)

34. P.U. Singare, M.P. Trivedi, R.M. Mishra, American Journal of Chemistry, 2(3), 171-180 (2012)

35. R.S. Lokhande, P.U. Singare, D.S. Pimple, The New York Science Journal, 4(9), 66-71 (2011)

36. P.U. Singare, R.S. Lokhande, S.S. Bhattacharjee, International Journal of Sustainable Society, 5(3), 296-308 (2013)

37. P.U. Singare, Interdisciplinary Environmental Review, 12(4), 298-312 (2011).

38. A. Verma, S. Balachandran, N. Chaturvedi, V. Patil, Zoos' Print Journal, 19(9), 15991605 (2004).

39. M. Chen, Ma, Lena Q., Soil Sci. Soc. Am. J., 65, 491 (2001).

40. G.H. Jeffery, J. Bassett, J. Mendham, R.C. Denny, Vogel's Textbook of Quantitative Chemical Analysis, Longman Scientific \& Technical, England, $5^{\text {th }}$ Edition, pp.87, 788 (1989).

41. B. Koukal, J. Dominik, D. Vignati, P. Arpagaus, S. Santiago, B. Ouddane, L. Benaabidate, Environ. Poll., 131 (1), 163-172 (2004).

42. K.M. Mohiuddin, H.M. Zakir, K. Otomo, S. Sharmin, N. Shikazono, Int. J. Environ. Sci. Tech., 7 (1), 17-28(2010).

43. E.C. Okafor, K. Opuene, Int. J. Environ. Sci. Tech., 4 (2) 233-240 (2007).

44. EPA. Ambient water quality criteria for lead - 1984. U.S. Environ. Protection Agency Rep. 440/5-84-027. pp.81 Available from Natl. Tech. Infor. Serv., 5285 Port Royal Road, Springfield, Virginia 22161 (1985).

45. J.S. Feierabend, A.B. Russell, (eds.), Lead poisoning in wild waterfowl - a workshop. National Wildlife Federation, 1412 Sixteenth St. NW, Washington, D.C. pp.139 (1986).

46. FWS. Use of lead shot for hunting migratory birds in the United States. Final supplemental environmental impact statement. pp.535 Available from U.S. Fish Wildlife Service, Office of Migratory Bird Management, Washington, D.C. 20240 (1986).

47. R. Lansdown, W. Yule (eds.), Lead toxicity. History and environmental impact, Johns Hopkins Univ. Press, Baltimore, Maryland. pp.286 (1986).

48. L.J. McDonald, Can. Vet. J., 27(3), 131-134 (1986).

49. G.C. Sanderson, F.C. Bellrose, Illinois Natural History Survey, Spec. Publ. (SP-04). 1-34 (1986). 
50. N.S. Tiwana, N. Jerath, G. Singh, M. Ravleen (Eds.), Heavy metal pollution in Punjab Rivers, in Newsletter Environmental Information System (ENVIS), Punjab State Council for Science and Technology, India, 3(1) (2005).

51. Centre for Ecological Sciences., IISc Environmental Hand Book-Documentation on Monitoring and Evaluating Environmental Impacts of Environmental Standards, Vol.3, Indian Institute of Science, Bangalore (2001).

Available at http://wgbis.ces.iisc.ernet.in/energy/HC270799/HDL/ENV/START.HTM (Accessed on 01 March 2010).

52. US EPA. Wildlife Exposure Factor Handbook. Vol. 1 EPA/600/R-93/187a (1993).

53. M. T. Horne, W.A. Dunson, Archives of Environmental Contamination and Toxicology 29(4) 500-505 (1995).

54. B. Taub Frieda, Fish 430 lectures (Biological Impacts of Pollutants on Aquatic Organisms), University of Washington College of Ocean and Fishery Sciences, Seattle, WA (2004).

55. L.T. Haber, L. Erdreicht, G.L. Diamond, A.M. Maier, R. Ratney, Q. Zhao, M. Dourson, Regul. Toxicol. Pharmacol., 31(2), 210-230 (2000).

56. V. Diagomanolin, M. Farhang, M. Ghazi-Khansari, N. Jafarzadeh, Iran, Toxicol. Lett., 151 (1), 63 (2004).

57. F.W. Sunderman (JR.), S.M. Hopfer, M.C. Plowman, J.A Knight, Res. Commun. Chem. Pathol. Pharmacol., 70 (1), 103 (1990).

58. N. Johri, G. Jacquillet, R. Unwin, BioMetals, 23(5), 783-792 (2010).

59. G. Nordberg, K. Nogawa, M. Nordberg, L. Friberg, Cadmium. In: Handbook on toxicology of metals. Nordberg, G., Fowler, B., Nordberg, M., Friberg, L. editors New York: Academic Press, p. 65-78 (2007).

60. A. Bernard, Biometals, 17(5), 519-523 (2004).

61. J. Godt, F. Scheidig, C.G. Siestrup, V. Esche, P. Brandenburg, A. Reich, D.A. Groneberg, J. Occup. Med. Toxicol., 1, 22 (2006).

62. L. Favretto, B. Campisi, E. Reisenhofer, G. Adami, Anal. Chim. Acta, 344(3), 251-259 (1997).

63. J.M. Pacyna, M.T.Scholtz, Y.F. Li, Environ. Rev., 3(2), 145-159 (1995).

64. D. Gosh, S. Datta, S. Bhattacharya, S. Mazumder, Aquat. Toxicol., 81(1), 79-89 (2007).

65. D. Gosh, S. Datta, S. Bhattacharya, S. Mazumder, Comp. Biochem. Physiol., 143C: 455463 (2006).

66. W.N. Rom, Environmental and Occupational Medicine. $4^{\text {th }}$ Ed. by Lippincott Williams \& Wilkins (2007).

67. Omprakash Sahu, International Letters of Natural Sciences 7 (2014) 35-43.

68. Piotr Daniszewski, Ryszard Konieczny, International Letters of Chemistry, Physics and Astronomy 4 (2013) 91-97.

69. Piotr Daniszewski, Ryszard Konieczny, International Letters of Chemistry, Physics and Astronomy 4 (2013) 98-104. 
70. Piotr Daniszewski, International Letters of Chemistry, Physics and Astronomy 4 (2012) 119-124.

71. Emil Cyraniak, Piotr Daniszewski, Beata Draszawka-Bołzan, International Letters of Chemistry, Physics and Astronomy 5 (2012) 88-95.

72. Emil Cyraniak, Piotr Daniszewski, Beata Draszawka-Bołzan, International Letters of Chemistry, Physics and Astronomy 5 (2012) 96-103.

( Received 01 May 2014; accepted 08 May 2014 ) 